\title{
Yükseköğretimde Fırsat Eşitliği, Nizamiye Medreseleri
}

\author{
Opportunity Equality in Higher Education - Nizamiye Madrasahs
}

\section{Bahar BERBEROĞLU*}

Geliş Tarihi: 29.05.2019 草 Kabul Tarihi: 29.06.2019 $\quad$ Kayın Tarihi: 01.07.2019

\section{Özet}

Büyük Selçuklu Devleti'nin veziri Nizam'ül Mülk'ün 'Nizamiye Medreseleri'ni açması yükseköğretimde önemli bir yeniliktir. Bu medreselerin açılmasının başlıca amaçları, İslamiyet'i yayacak ve yaşatacak üst düzey din ve devlet adamlarını, devlet hizmetinde yer alacak Sünnî ve Hanefî inanca sahip ahlâklı memurları, yoksul ve yetenekli öğrencileri yetiştirmekti. Bu medreseler yükseköğretim olanağını maddi durumu iyi olan, olmayan tüm öğrencilere verdiğinden, yükseköğretimde fırsat eşitliği sağlamaktaydı. Bu kurumlar sadece müderris, müid konumundakilere yüksek maaş vermiş, öğrencilerine de yatılı-burslu olma olanağ1 sağlamıştır. Medreselerin şehirlerden kasabalara kadar önemli yerleşim yerlerinde açılmasıyla, yükseköğretim tabana yayılmış, fırsat eşitliği sağlanmıştır. Selçuklu Medreseleri, Avrupa'da başlayan 'Aydınlanma Çağı'na katkı sağlayarak o dönem Avrupa'daki üniversitelere iyi bir örnek oluşturmuştur. Selçukluların yükseköğretim tecrübeleri, kendisinden sonra gelen Anadolu Beylikleri ve Osmanlı Devleti'ndeki yükseköğretimine önemli bir temel teşkil etmiştir. Biz bu çalışmamızda, Nizamiye medreselerindeki fırsat eşitliğini inceleyerek, bu kavramın önemine ve toplumsal getirilerine dikkat çekmek ve günümüze yansımalarını değerlendirmek istiyoruz. Bu konu ile ilgili kaynak taramamızda eğitimde fırsat eşitliği kavramını geçmişten günümüze değerlendireceğiz. Selçuklularda olduğu gibi, günümüzde de devletlerin, yükseköğretimi en önemli görevleri arasında kabul ederek, bireylerin tamamına eşit olanaklarla bu hizmeti sunması gerekmektedir. Ulusal eğitim politikalarında dezavantajlı gruplar için açık ve uzaktan öğretimin kullanılması, yaşam boyu öğrenme olanaklarının halkın hizmetine sunulması ve böylece beşerî sermayenin geliştirilmesine olanak sağlaması mümkündür. Çalışmamızda, devletin yükseköğretim politikaları oluşturması ve eğitim ve öğretimde fırsat eşitliği sağlaması konularının Batıdan öğrendiğimiz kavramlar değil, Batının bizden öğrendiği kavramlar olduğunu ortaya koymaya çalışacağız.

Anahtar Kelimeler: Yükseköğretimde fırsat eşitliği, selçuklu yükseköğretim sistemi, nizamiye medreseleri

\section{Abstract:}

\footnotetext{
* Prof. Dr., Anadolu Üniversitesi, Açıöğretim Fakültesi, Eskişehir, Türkiye. E-mail: $\underline{\text { bdirem@anadolu.edu.tr }}$
} 
The establishment of Nizamiye Madrasahs by the vizier of the Grand Seljuk State, named Nizam'ül Mülk, is an important innovation in higher education. The main objective of establishing these madrasahs were to educate poor and talented students with Sunni and Hanafi beliefs and prepare them for being ethical high-level religious staff and statesmen with the duty of spreading Islam and then employ these people in state services and in spreading Islam. These institutions gave equal opportunities for higher education to all students who are in good or bad financial situations. These institutions have only employed well-trained senior tutorial in education with high salaries and have provided boarding-scholarship for all of the students. With the opening of madrasahs in all important settlements from cities to towns, higher education has spread all over the Grand Seljuk State and equal opportunity has been provided for all the people. This phenomenon has contributed to the Age of Enlightenment which started in Europe and set a good example for the universities in Europe. The higher education experiences of the Seljuks also provided an important basis for the higher education of the Anatolian Principalities and the Ottoman Empire. In this study, we aimed to examine the equality of opportunity in Seljuk higher education system and to draw attention to the importance and social benefits of this concept and to evaluate its reflections to our day. We will evaluate the concept of equality of opportunity in higher education from the past to the present by conducting a literature review. As in the Seljuks, today for all governments it is necessary to offer higher education to all individuals with equal opportunities by considering this service among the most important tasks. In national educational policies, it is possible to provide opportunities of lifelong learning for disadvantaged groups and for all the people by using open and distance learning, thus enabling the development of human capital. The formation of higher education policies of the state and providing opportunity equality in education and training are not the concepts which we learned from the West, but they are the concepts were learned by the West from us.

Keywords: Opportunity equality in higher education, seljukian higher education system, nizamiye madrasahs

\section{Giriş}

Eğitim öğretim bir milletin hayatında önemli bir yere sahiptir. Bu konuya önem veren toplumlar, tarih sahnesinde köklü devletler kurmuş ve uzun yıllar hüküm sürmüşlerdir. Bu gerçeği iyi bir şekilde kavrayan Türkler, Selçuklular döneminde 'medrese' denilen eğitim-öğretim kurumları tesis etmişlerdir. Onların takipçileri olup devraldıkları mirası mükemmel bir biçimde değerlendirmeyi başarabilen Osmanlılar, daha da ileriye gitmiş ve sonuçta bir cihan devleti olmayı başarmışlardır (Hızlı, 1987).

Selçuklular, Dandanakan Savaşı ile Gazneli Devleti'ni ortadan kaldırdıktan sonra, İran merkezli bir devlet kurarken, sosyal, siyasi, iktisadi ve coğrafi açıdan bazı olumsuz şartları aşmada eğitimi bir araç olarak kullanmışlardır. Çünkü Selçuklular, İran, Türkiye, Suriye, Ermenistan, Azerbaycan ve Filistin topraklarını kapsayan geniş bir coğrafyada büyük ve güçlü bir devlet kurarken karşılaştıkları sosyo-politik zorlukları aşmayı doğru bir eğitim politikası izleyerek başarmışlardır. Bu eğitim politikasında oluşturulan temel öğretim kurumları medreseler olmuştur. Geçmişte yaşamış Selçuklu Türklerinin kurduğu eğitim düzenini ve sürecini en iyi şekilde 
tanımak, anlamak ve bu dönemin bilimsel zenginliğini kavramak bu çalışmanın önemini ve gerekliliğini bize göstermiştir.

11. yüzyılda Selçuklu Devleti'nin görünümünü Nizam'ül Mülk şekillendirmiştir. $\mathrm{Bu}$ vezir hem muhteşem bir devlet adamı hem de oldukça yetenekli bir yazardır. Nizam'ül Mülk Alp Arslan'ın sarayının sınırlarından çok daha ötesini düşünebilen ileri görüşlü bir vezirdi. Eğitimin imparatorluk coğrafyasında yayılması adına bu işi yapabilecek uygun insanları, kendilerini hukuk ve teoloji alanlarında çalışmaya adama konusunda ikna etmeye çalışmıştır. Resmi bildirilerinin ve talimatlarının birçoğunda bu insanlara neler yapmalarını önermiş ve bunların ilgilerini ve çabalarını arttırmak amacıyla öğretmen ve öğretim görevlilerinin maaşlarını yükseltmiştir. Ayrıca o zamanların en sivrilmiş, ünlenmiş kişilerin kullanımlarına sunmak amacıyla kütüphaneler yaptırarak bu insanları eğitim mesleğine çekmeye çalışmış, ayrıca bunlara saygın unvanlar yağdırmıştır. Bilimsel yöndeki çalışmaları genişletmek için eğitim müesseselerini yeniden organize etme işine girişmiş ve Nizamiye medreselerini kurmuştur (Rice, 2015). Bu medreselerde özenli bir biçimde yürütülen sistemli eğitim faaliyetleri sonucunda Nizâm'ül Mülk zamanından itibaren bu topraklarda kuşaklar boyu iyi eğitilmiş ulusal, dini ve ahlaki değerlere bağlı insanlar yetiştirilmiştir (Biçer, 2013).

Dolayısıyla Türk Dünyasında, sistemli ilk eğitim kurumları olarak medreseler Büyük Selçuklular devrinde Nizam'ül Mülk tarafından Nizamiye medreseleri adıyla kurulmuştur. Nizam'ül Mülk, âlim, dindar, cömert, âdil, yumuşak huylu, suçluları bağışlayan ve az konuşan bir insan olarak hatırlanmaktadır. Bu vezir görevde bulunduğu dönemde ilk olarak dini ilimleri ihya ederek, ilim ehlini desteklemiş ve himaye etmiştir. İlimle uğraşan insanlar onun zamanında saygınlık kazanmışlardır. Ayrıca o dönemde medreselerde sadece dini ilimler değil, bütün ilimlerin okutulması sağlanmıştır. Sultan Alp Arslan, Sultan Melikşah ve Vezir Nizam'ül Mülk zamanında Selçuklu Devleti Sünnî bir karakter kazanmıştır. Devletin siyasi, askeri ve mali alanda teşkilatlanmasında Nizam'ül Mülk belirleyici bir unsur olmuştur. Bu vezir, Sünnî bir Müslüman ve hamaset sahibi bir insan olarak tarihe geçmiştir. (Biçer, 2013).

$\mathrm{Bu}$ çalışmada, Nizamiye Medreselerinin kuruluş amaçları ve eğitim öğretim faaliyetlerinden söz edilirken, fırsat eşitliği kavramı ele alınmakta ve bu medreselerin günümüze yansımaları dikkate alınarak bir yükseköğretim kurumu olarak özellikle fırsat eşitliği sağlama yönündeki uygulamalarının ortaya konulması amaçlanmaktadır. Çalışmamızda özellikle bu medreselerin kuruldukları Orta Doğu ve Anadolu topraklarında ne kadar geniş bir bölgeye yayıldıkları ve bu medreselerle nasıl bir yükseköğretim ağ1 oluşturulduğu, geniş ve içeriği zengin tablolar oluşturularak göz önüne serilmiştir.

Bu çalışmada kullanacağımız yöntemler literatür (kaynak) taraması ve buradan üretilecek bilgilerin özetini tablolaştırma yoluyla bir bütün olarak gözler önüne sermektir. Var olan kaynak ve belgeleri inceleyerek veri toplamaya literatür taraması denir. Bu yöntem, veri toplama ve sonra elde edilen bu verinin öneminin tartışılması, 
araştırmada problemle ilişkisinin kurulması, bilginin tablolar aracılığıyla sınıflandırılması aşamalarından oluşmuş bir süreçtir (Balcı, 2001). Bu yöntem ile araştırma probleminin tanımlanarak anlaşılması ve araştırmanın tarihsel bir perspektife oturtulması sağlanır (Karasar, 1994).

\section{Literatür Özeti}

'Medrese' kelimesi, Arapça 'derase' kökünden gelmekte olup 'ders okunacak yer ve öğrencilerin içinde oturarak ders gördüğü bina' anlamını taşımaktadır. Bu kelimenin çoğul hali ise 'medaris' biçimindedir (Pakalın, 1971).

Abbasiler ilk devirlerinde eğitim-öğretim kurumları için 'medrese' ismini kullanmamışlardır. Bu kelime ilk olarak 11. Yüzyılda kullanılmaya başlanmıştır (Dağ ve Öymen, 1976). Medreselerin resmi bir kurum olarak devlet tarafından kurulması ise Karahanlılar döneminde gerçekleşmiştir. Arslan Gazi Tafgaç Han, Merv kentinde 1035 yılında bir medrese yaptırmıştır (Sayılı, 1947-1948). Ancak İslam tarihçileri, medreselerin ilk kurucusu olarak Nizam'ül Mülk (485/1092) üzerinde bir fikir birliği içerisindedirler (Zeydan, 1329; Hızlı, 1987). Medreselerin kiminle başlatıldığ konusunda ise Ahmet Çelebi aynı sonuca ulaşmakta ve en ince teferruatına kadar teknik manada medreseleri ilk kuran kişinin Nizam'ül Mülk olduğunu ileri sürmektedir. Bu yazara göre, daha önce ortaya çıkan benzer kurumlara 'medrese' tabirinin kullanılmasına gelince bunlar, uzun ömürlü olmayan ve İslami hayatta kuvvetli bir iz bırakmayan mahdut ve sathı gayret mahsulü müesseselerdir (Çelebi, 1983).

Tarihte medreselerin geniş anlamda devlet eliyle kurulması, öğrenim masraflarının devlete ait olması ve medrese teşkilâtının en küçük ayrıntılarına kadar tespiti ve o zamanki yükseköğretime ait tüm bu planlamaların hassasiyetle gerçekleştirilmesi Selçukluların eseridir Medreseler Şii ve Batinilere karşı ehl-i sünnet düşüncesini korumak amaciyla kurulmuştur. Medreseler sayesinde Sünni İslam düşüncesi gayri Sünni unsurlara karşı mutlak bir üstünlük kazanmıştır.

Nizâm'ül Mülk medreseleri kurmadan önce buralarda yürütülecek ders programlarını ve eğitimin temel esaslarını belirlemişti. Vakfiyeler tarafından yapılan desteklerle medreselerin Şafi fıkhına göre hizmet ve eğitim yapmasını öngörerek gerekli kuralları belirlemiştir. Nizamiye medreselerinde usul ve füru düzenlemelerinde Şafi fıkhı esas alınmıştır. Mütevelli heyetler, müderrisler, vaizler ve kütüphane görevlilerinin tamamı Şafi mezhebinden seçilmiştir. Medreseler daha çok fıkıh medreseleri olarak eğitim yaparken Şafi Fıkhı'nı ve akide de ise, Eş'ari mezhebini esas almışlardır. Bu nedenle Nizamiye medreseleri Şafi fıkhını esas alarak eğitim yapan fıkıh medreseleri olarak toplumun mezhep çatışmalarını önlemişlerdir (Biçer, 2013).

Nizamiye Medreselerine çarşı, han, hamam ve çiftlikler vakfedilmiş, bu vakıfların sağlamış olduğu bu olanaklar sayesinde yükseköğretim hakkının maddi 
durumu iyi olan ve olmayan herkese verilebilmesi olmuştur. Böylece toplum katmanları arasında bir fırsat ve imkân eşitliği sağlanmıştır. Bu konuda gençleri bilgi peşinde koşmaya yönelten Kûfeli Arap Ebû Amr İshak b. Mirâr esSeybânî'nin şu ifadesi son derece önemlidir: 'Eğitim, fakirlere zenginlerin halılarını çiğneme imkânı verir (Makdisî, 2004). Bu çerçeveden bakıldığında bir devlet politikası olarak, devlet eliyle plânlı eğitim öğretim yapılmasının ve eğitimde fırsat eşitliği sağlanmasının öneminin kavranması konusunda öncü toplumun Türk-İslam yapısına sahip Selçuklular olduğu anlaşılmaktadır.

Bilindiği gibi eğitim ve öğretimde fırsat eşitliği ilkesi, toplumu oluşturan bireyler arasında ayrım yapılmaksızın herkese, yeteneklerini en uygun biçimde geliştirmede eğitim ve öğretim hizmetlerinden eşit ölçüde yararlanma şansının verilmesi anlamını tanımaktadır. Bu ilkenin temel amacı, insanların sosyal statülerini geliştirme ve hayatlarını kazanmalarında eşit koşullar altında mücadele etmelerini sağlamaktır. Bazı kişilerin diğerlerinden farklı olarak karşılarına çıkan sosyal ve ekonomik engelleri eşitlemeye çalışmak ve bazı kişilerin sahip olduğu imtiyazları ortadan kaldırmak bu ilkenin bir başka amacıdır. Bu sayede herkes, mensup oldukları sosyal ve ekonomik durumlarına bakılmaksızın, istek ve kabiliyetlerine göre toplumdaki yerlerini alabilme, şahsiyetlerini ve isteklerini tam olarak gerçekleştirebilme olanaklarına sahip olabilmelidir (Ergün, 1997). Eğitimde fırsat eşitliği, gerçekten hem arzu edilebilir ve hem de uygulanabilir bir amaçtır (Illich, 2013). Diğer bir tanımla eğitimde fırsat eşitliği, düşük eğitimli olan ve düşük ücretle çalışan bir ailenin çocuğunun da iyi şartlarda eğitim almasını sağlamaktır (Aslankurt, 2013).

Modern toplumlarda, bireylerin içinde bulundukları gelir grubuna bakılmadan, toplumsal konumlarını değiştirecek ve iyileştirecek eşit fırsatlara sahip olmaları gerektiği bir ilke olarak kabul edilmektedir. Fırsat eşitliğinin sağlanmasıyla, eğitimin farklı sınıf ve tabakalara açık hale getirilmesi anlamına gelen yaygın eğitim aracılığıyla da toplumsal hareketliliği sınırlanmış olan alt gelir gruplarından olan bireylere, bilgi, beceri ve yetenek kazandırılarak toplumsal konumlarını iyileştirme olanaklarının sağladığı görülmektedir (Suğur, 2008). Diğer bir ifade ile eğitimde tam bir fırsat eşitliği sağlanamasa da eğitimden yaralanmada eşitlik (Tan, 1987) mümkün olduğu oranda sağlanmaya çalışılmaktadır.

Eğitimde fırsat eşitliği sayesinde herkese eşit düzeyde eğitim vermek, herkesi belli bir performansa sahip kılabilmek ve herkesi aynı performans düzeyine getirmek, herkesin tüm hayallerini ve beklentilerini gerçekleştirebilmesini sağlayacak eğitimi almasını güvenceye alması sağlanmalıdır. Ayrıca, tüm toplumlardaki her tür etnik, mesleki, cinsiyet ve öteki grupların yönetimde oransal temsilini sağlamak, bireylerin yararlanıp yararlanmadığına bakılmaksızın eğitime girişte tüm bireylere fırsat eşitliği sağlamak, herkesin ek öğrenim olanaklarına ulaşma oranının birbirine eşit olduğu bir noktaya ulaşmasını mümkün kılmak ve vatandaşların içinde bulunduğu dengesizliği ortadan kaldırmak eğitimde fırsat eşitliği ile mümkün olacaktır (Tan, 1987; Başaran, 1982; Onuncu Kalkınma Planı, Özel İhtisas Komisyon Raporu, 2013; İnan ve Demir, 
2018). Zaten, eğitimde fırsat eşitliğini sağlayarak toplumun her kesimini eğitim hizmetlerinden yararlandırmak, demokratik rejimlerin temel hedeflerinden birisi olmak durumundadır (Karagözoğlu, 1985).

Günümüzde tüm kamu yönetimleri elindeki olanakları tüm vatandaşlarına adil bir biçimde sunmayı hedeflemelidirler. Ancak sosyo-ekonomik olanakları yetersiz olan kesimlere sunacağ 1 farklı alternatiflerle farklı destekler sağlayarak bu kişiler için de eğitim ve öğretim açısından fırsat eşitliği yaratmalıdır. Özellikle gelir düzeyleri ve bölgeler arası önemli farklılıkların bulunduğu azgelişmiş ve gelişmekte olan ülkeler bakımından fırsat eşitliği çok daha önemlidir. Gelir düzeyleri, yaşadıkları bölge ve sahip oldukları kültür düzeyi, demografik yapıları birbirinden her ne kadar farklı olursa olsun toplumun tümünün sunulan hizmet ve olanaklardan adil bir biçimde yararlanabilme olanağına sahip olması büyük önem taşımaktadır (İnan ve Demir, 2018).

Fırsat eşitliği açısından Türkiye'nin imzalamış olduğu uluslararası anlaşmalara baktığımız zaman, ilk olarak karşımıza Birleşmiş Milletler İnsan Hakları Evrensel Bildirgesi çıkmaktadır. Bu bildirgenin 26. maddesi 1. fikrasında; "Herkes eğitim hakkına sahiptir. Eğitim, en azından ilk ve temel eğitim aşamasında parasız olmalıdır. İlköğretim zorunludur. Teknik ve mesleksel eğitim herkese açıtır. Yükseköğretim, yeteneklerine göre herkese tam bir eşitlikle açık olmalıdır" (Aydın, 2000) ifadesi yer almaktadir.

1982 Anayasa'sının yükseköğretim kurumlarını düzenleyen 130. maddesine göre ise; "Çağdaş eğitim-öğretim esaslarına dayanan bir düzen içerisinde milletin ve insanların ihtiyaçlarına uygun insan gücü yetiştirmek amacı ile; orta öğretime dayalı çeşitli düzeylerde eğitim-öğretim, bilimsel araştırma, yayın ve danışmanlık yapmak, ülkeye ve insanlığa hizmet etmek üzere çeşitli birimlerden oluşan kamu tüzel kişiliğine ve bilimsel özerkliğe sahip üniversiteler devlet tarafından kurulur. Kanunda gösterilen usul ve esaslara göre kazanç amacına yönelik olmamak şartı ile vakıflar tarafından, devletin gözetim ve denetimine tabi yükseköğretim kurumları kurulabilir" ifadesi yer almaktadır. Anayasanın bu maddesi ile orta ve yükseköğretimde herkesin eğitim olanaklarına kavuşturulması ile eğitimde fırsat eşitliğinin ağlanması amaçlanmaktadır (İnan ve Demir, 2018).

Türkiye' de 1960'lı yılların başından beri “Planlı kalkınma” dönemi olarak anılan ve bugün de bazı aksamalara karşın kısmen süren dönem, eğitim sisteminin yönlendirilmesinde ekonomik ölçütlerin belirgin biçimde ağırlık taşıdığ 1 bir dönem olarak görülebilmektedir. Bu planlarda eğitim kavramı kazandırdığı çeşitli değerler, davranışlar, kişilik özellikleri ve yeteneklerle kişilerin refah ve mutluluklarını arttıran, ülke kalkınmasına katkı sağlayan toplumsal bir araç/ hizmet/ süreç/ yolu olarak görülmektedir.

Kalkınma planlarında eğitim sistemine ait öngörülen hedeflerin gerçekleştirilmesinde bazı politikalar devreye sokulmuştur. Bunlardan biri, öğrenci akışı ve yönlendirme politikalarıdır. Bu politika çerçevesinde bireylerin öğrenim 
görme isteklerinin artırılmasına ağırlık vermek yerine, öğrenim görmek isteyenler kişiler arasından yetenekli olanları yükseköğretime hazırlayacak ortaokul ve genel liseleri kurmak ve bunların programlarını hazırlamak ve bu kişileri bu yönde ilerletmek amaçlanmışır. Daha az yetenekli öğrencileri ise mesleğe hazırlayacak mesleki-teknik lise ve yaygın meslek eğitimine yöneltmek üzere bu tür öğretim olanaklarını genişletmek ve yoğunlaştırmak hedeflenmiş̧ir. Ama maalesef bu hedeflere ulaşmak mümkün olamamıştır. Toplumun geniş bir kesiminin istediği alanda eğitim hakkından mahrum bırakılmasına neden olan bu yaklaşım, liberal bir eşitlik anlayışı olan 'fırsat eşitliği' ilkesi ile meşrulaştırılmaya çalışılmıştır (Küçüker, 2010).

Onuncu Kalkınma Planının politikalar başlığında ise, "Eğitim sisteminde, bireylerin kişilik ve kabiliyetlerini geliştiren, hayat boyu öğrenme yaklaşımı çerçevesinde işgücü piyasasıyla uyumunu güçlendiren, fırsat eşitliğine dayalı, kalite odaklı dönüşüm sürdürülecektir" (Onuncu Kalkınma Planı, 2013) ifadesi ile eğitimde fırsat eşitliği hedeflenmiştir. Bu hedefe de tam olarak ulaşılamasa bile, önemli bazı gelişmeler sağlanabilmiştir.

Kısacası, eğitimde fırsat eşitliği açısından Türkiye'de uygulanan kamu politikaları olarak; zorunlu temel eğitim, taşımalı sistem (taşımalı eğitim/okul servisleri), parasız eğitim (parasız devlet okulları), burslu eğitim/öğrenci bursları (öğrenim kredisi uygulaması), uzaktan eğitim, çok amaçlı eğitim, yetiştirici ve tamamlayıcı sınıflar ve kurslar düzenleme/açma, bölge okullarının kurulması, özel eğitime muhtaç çocuklara eğitim olanağı sağlanması, ücretsiz ders kitabı ve şartlı eğitim yardımları şeklinde sıralanan bazı hizmetlerin gerçekleştirilmesi mümkün olmuştur. Bu yapılanların yetersiz kalması nedeniyle, halen Ülkemizde eğitimde fırsat eşitliğini olumsuz yönde etkileyen en önemli faktörler olarak genel hatlariyla; gelir dağılımı, ekonomik yapı, sosyal yapı ve siyasi istikrar sorunları biçiminde sorunların çözülmesi gerektiğini belirtebiliriz (İnan ve Demir, 2018).

\section{Bulgular}

Siyaset, devlet işlerini düzenleme ve yürütme sanatıyla ilgili özel görüş veya anlayışı ifade etmektedir. Aynı zamanda siyaset toplum ve devlet yönetimiyle ilgili olduğundan, toplumu oluşturan bireylerin eğitimleri, siyasetin ilgi alanına girmektedir. Böylece her siyasi görüşün bir eğitim politikası olması da kaçınılmazdır. Politika ise, devletin etkinliklerini amaç, yöntem ve içerik olarak düzenleme ve gerçekleştirme esaslarının bütünü olarak tanımlanmaktadır. Başka bir anlatımla politika, ülke ve devlet yönetimiyle ilgili olduğundan eğitimin de felsefi, sosyolojik, hukuki, ekonomik ve tarihi tüm boyutlarıyla ilgili bulunmaktadır (Serçe, 2016).

Türklerin tarihine baktığımızda ise Selçuklularda özellikle devletin siyasi, askeri ve mali alanda teşkilatlanmasında bir vezirin belirleyici bir unsur olduğu görülmektedir. Bu vezir, İmam'ül-Haremeyn hutbede; “Cömertlerin efendisi, dinin ve 
dünyanın destekçisi, ümmetin öncüsü, kalem ve kılıcın hizmetkârı" olarak tanımladığı Nizâm'ül Mülk'tür (Biçer, 2018).

Nizam'ül Mülk ile resmi olarak başlatılan medreselerin kurulmasının en önemli nedeni, Allah'u Teala'ya hâlis olarak ibadet edecek kullar yetiştirmek ve insan hayatını bu amaç için tanzim etmekti (Biçer, 2013). Bunun dişında bu medreselerin sayesinde olarak içinde bulunulan yıllarda oldukça güçlenmiş Batınî propagandasına karşı koymaktı. Bu şekilde korunan ehli sünnet alimleri ve sûfileri, İslam'ın ve Selçuklu Devleti'nin bünyesini güçlendirmek konusunda başarılı olabilmişlerdi (Köprülü, 1980; Hizlı, 1987).

Medreselerin kurulmasındaki ikinci önemli neden ise, o güne kadar kullanıla gelmiş olan mescitlerin eğitim-öğretim faaliyetleri için yeterli olmamasıdır. Öğrenci sayısının artması (Yurdaydın, 1971), ders programlarının genişlemesi, gelişen diğer bilimlerin ve İslami ilimlerin belirli bir düzenle verilmesi (Tekindağ, 1973), eğitimöğretimin mescitlerden medreseye geçişini gerekli kılmıştır (Hızlı, 1987).

Mescitlerden medreseye geçişi gerekli kılan bir başka neden eğitim-öğretim metotlarının değişmesiydi. Çünkü Kelâm gibi, ilim dallarının eğitim ve öğretimi tartı̧̧malı ve karşılıklı atışma biçiminde yapıldığından, bu öğretim tarzı, temel amaçları ibadet imkânı sağlamak olan mescitlerde olması gereken sükûnet ve huzur anlayışına ters düşmekte idi (Çelebi, 1983).

Medreselerin bunlardan sonra gelen başka önemli nedenleri ve amaçları şöyle sıralanabilir:

1. Memurların, üst düzey yöneticilerin (müderris, kadı, komutan gibi), devletin kontrolü altındaki okullardan yetiştirilmesi.

2. İslamiyet'in tanıtılması, yayılması ve İslamiyet'i yaşatacak ilim adamlarını yetiştirilmesi, bu sayede Farklı milliyetlere mensup insanların yaşadığ topraklarda kalıcı olunabilmesi.

3. Sünni ve Hanefi inanca sahip insanların yetiştirilmesi.

4. Üst düzey din adamları (müftü, vaiz, imam, müezzin) yetiştirilmesi. Dört Hak mezhebe mensup aydınlar eğitilmesi ve böylece Şii, Fatımi ve diğer inanç gruplarının kara propagandasının önüne geçilmesi, özellikle Selçuklunun aleyhinde toplumu etkilemeye çalışan Şeyh, Şıh, Molla gibi kişilerin medreselerde görevlendirilerek devlet denetimi altına alınması.

5. Devlet kadrolarını yenileyerek, devletin sosyal temellerinin sağlamlaştırması (Köymen, 1975).

6. Eğitimde fakir çocukların da eğitim kurumlarından faydalanmasının sağlanması, eğitimde fırsat eşitliğinin geliştirilmesi,

7. Selçuklu şehirlerinin mimari güzelliklerine katkıda bulunması (Sönmez ve Celkan, 2018). 
Böylesine önemli amaç ve nedenlerle kurulan Nizamiye Medreseleri Selçukluda yükseköğretimin bir devlet politikası olarak kullanılmasında önemli bir role sahip olmuştur. Böylece, yukarıda belirtilen 6. Maddede belirtildiği üzere Selçukluların eğitim ve öğretimde fırsat eşitliğinin sağlanmasının önemini kavramış ve bunun için çaba harcamışlardır. İslamiyet'in ve yükseköğretimin yayılmasında büyük katkısı olan bu medreseler şu an Türkiye Cumhuriyeti sınırları içinde ve dişında bulunan büyük bir coğrafyada kurulmuşlardır. Bunlar Tablo 1 ve Tablo 2' de verilmiştir:

Tablo 1. Türkiye dışındaki Medreselere ait bilgiler

\begin{tabular}{|c|c|c|c|c|}
\hline Medrese Ad1 & Medrese Yeri & Yapılış Tarihi & Yaptıran Kişi & Eğitim Türü \\
\hline $\begin{array}{l}\text { Amul Nizamiye } \\
\text { Medresesi }\end{array}$ & $\begin{array}{l}\text { Amûl } \\
\text { (Taberistan) }\end{array}$ & 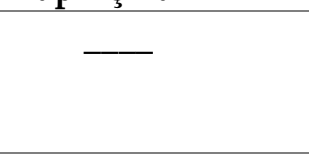 & Devlet & $\begin{array}{l}\text { Hanefî ve Şafi'î } \\
\text { fıkıhları ve pozitif } \\
\text { bilimler }\end{array}$ \\
\hline $\begin{array}{l}\text { Bağdat Nizamiye } \\
\text { Medresesi }\end{array}$ & Bağdat & $\begin{array}{l}1065 \text { başland1 ve } \\
1067^{\prime} \text { de açıldı }\end{array}$ & Devlet & $\begin{array}{l}\text { Hanefî ve Şafi'î } \\
\text { fıkıhları ve pozitif } \\
\text { bilimler }\end{array}$ \\
\hline $\begin{array}{l}\text { Basra Nizamiye } \\
\text { Medresesi }\end{array}$ & Basra & $\ldots$ & Devlet & $\begin{array}{l}\text { Hanefî ve Şafi'î } \\
\text { fıkıhları ve pozitif } \\
\text { bilimler }\end{array}$ \\
\hline $\begin{array}{l}\text { Herat Nizamiye } \\
\text { Medresesi }\end{array}$ & Herat & $\begin{array}{l}1085^{\prime} \text { te faal } \\
\text { durumda } \\
(1070-1080)\end{array}$ & Devlet & $\begin{array}{l}\text { Hanefî ve Şafi'î } \\
\text { fıkıhları ve pozitif } \\
\text { bilimler }\end{array}$ \\
\hline $\begin{array}{l}\text { İsfahan } \\
\text { Nizamiye } \\
\text { Medresesi }\end{array}$ & İsfahan & $1072-1092$ & Devlet & $\begin{array}{l}\text { Hanefî ve Şafi'î } \\
\text { fıkıhları ve pozitif } \\
\text { bilimler }\end{array}$ \\
\hline $\begin{array}{l}\text { Merv Nizamiye } \\
\text { Medresesi }\end{array}$ & Merv & $1075-1076$ & Devlet & $\begin{array}{l}\text { Hanefî ve Şafi'î } \\
\text { fıkıhları ve pozitif } \\
\text { bilimler }\end{array}$ \\
\hline $\begin{array}{l}\text { Musul Nizamiye } \\
\text { Medresesi }\end{array}$ & Musul & 1092'den önce & Devlet & $\begin{array}{l}\text { Hanefî ve Şafi'î } \\
\text { fıkıhları ve pozitif } \\
\text { bilimler }\end{array}$ \\
\hline $\begin{array}{l}\text { Nişabur } \\
\text { Nizamiye } \\
\text { Medresesi }\end{array}$ & Nişabur & 1046 & Devlet & $\begin{array}{l}\text { Hanefî ve Şafi'î } \\
\text { fıkıhları ve pozitif } \\
\text { bilimler }\end{array}$ \\
\hline $\begin{array}{l}\text { Rey Nizamiye } \\
\text { Medresesi }\end{array}$ & Rey & 1060 & Devlet & $\begin{array}{l}\text { Hanefî ve Şafi'î } \\
\text { fıkıhları ve pozitif } \\
\text { bilimler }\end{array}$ \\
\hline $\begin{array}{l}\text { Belh Nizamiye } \\
\text { Medresesi }\end{array}$ & Belh & $1078-1079$ & Devlet & $\begin{array}{l}\text { Hanefî ve Şafi'î } \\
\text { fıkıhları ve pozitif } \\
\text { bilimler }\end{array}$ \\
\hline $\begin{array}{l}\text { Tus Nizamiye } \\
\text { Medresesi }\end{array}$ & Tus & $\ldots$ & Devlet & $\begin{array}{l}\text { Hanefî ve Şafi'î } \\
\text { fıkıhları ve pozitif } \\
\text { bilimler }\end{array}$ \\
\hline
\end{tabular}

Nizam'ül Mülk tarafından 1067 tarihinde Bağdat'ta açılmış olan Nizamiye Medresesi bugünkü manada kurulan ilk resmi eğitim kuruluşudur. Burada İmamGazali olmak üzere büyük bilginler yetişmiştir (Kayadibi, 2001). 
Nizamiye Medreseleri özellikleri bakımından klasik eğitim veren medreselerden ayrılmıştır. Her şeyden önce bu kurumlar, merkezinde medresenin yer aldığ 1 külliye biçiminde tasarlanmıştır. Nişabur Nizamiye Medresesi bu yapılanmanın en önemli temsilcisidir. Medreseye ek olarak kütüphane, hastane, mescit ve hânkâh da bu yap1 grubu içindedir. Farklılıklar bunlarla da sınırlı değildir. Ders programları, öğrencilerin tüm yemek, yatak ve ders araçlarının karşılanması da bu farklılıklar arasındadır.

Günümüzdeki Hukuk, İlahiyat, Edebiyat, Siyasal Bilgiler ve belli oranda da Fen Fakültesi müfredatını birleştiren Nizamiye Medreselerinde, başta Kur'an olmak üzere hadis, fikıh, usûl, Eşarî kelâmı, hilâf, cedel, ferâiz, Arapça, edebiyat, sarf, nahiv, lügat, Şiîr, hitabet, tarih, coğrafya, musiki, hat, felsefe, mantık, riyâziye, hendese, hesap, nücûm ve hukuk konularında dersler verilmiştir (Göksu, 2018).

Nizam'ül Mülk, medreseleri o güne kadar bir örneği bulunmayan vakıf sistemi içinde kurmuştur. Bir vakıf okulu sayılabilecek bu medreseler, hayır sahiplerinden toplanan yardımlar veya tahsis edilen gelir getiren kurumlarla (akarlarla) kurulmuş ve tüm ekonomik ihtiyaçlar bu bütçe ile karşılanmıştır. Öğretim elemanlarına maaş ve öğrencilere burs veren tarihte ilk okul Nizamiye medreseleridir (Leiser, 1986). Bu sisteme göre maddi olanağı olmayan ama okumak isteyen yetenekli öğrencilere çok büyük bir fırsat eşitliği tanınmıştır. Çünkü böyle bir sistem geliştirilmeden önce yürütülen eğitim özel sayılabilecek nitelikte; sadece zengin ailelerin üstesinden gelebileceği ağır bir yük durumundaydı (Köymen, 2001; Okumuşlar, 2008).

Nizam'ül Mülk, müderris atama yetkisini kendisinde bulundursa da vakıfların yönetim yetkisini tamamen mütevelli heyetine bırakmıştır. Böylece devletin medrese üzerindeki otoritesinin sınırlandırılmasını garanti altına almıştır. Sonuç olarak da o dönemde artan İslami düşüncenin çeşitliliğine ayak uydurmak için İslami bilgiye ilginin artmasına uygun olarak biçimlendirilen bir eğitim sağlanmıştır (Tibawi, 1962; Winkelmann, 2005; Okumuşlar, 2008).

Medreselerde ilmi kalite, güven ve düşünce özgürlüğü olmasından dolayı İslam Dünyasının değişik ülkelerinden ve bölgelerinden insanlar gelerek eğitim görmüş ve sonra da kendi ülkelerine dönerek müderris, kadı, bürokrat olarak oralarda hizmet vermişlerdir. Bu sayede o bölgelerde de İslamiyet'in ve Sünniliğin yayılmasını sağlamışlardır (Brockelmann, 1991; Ocak, 2009). Özellikle Endülüs ve Kuzey Afrika'dan (Fas, Cezayir, Tunus) öğrenciler bu medreselerde okumuş ne ülkelerine döndüklerinde o bölgede İslamiyet adına büyük etkiler yaratmışlardır.

Endülüs'te (İspanya'da) başta Kurtuba olmak üzere çok sayıda medreseler kurulmuş ve buralarda Müslüman öğrenciler gibi batılı Hristiyan öğrenciler de öğrenim görmüştür. Avrupa birçok eğitim kuruluşu bu medreseleri örnek alarak yeniden yapılanmışlardır. Ayrıca bu medreselerde öğretilen müfredattan ve bilgilerden büyük ölçüde yararlanmışlardır. Bunun için Ziya Paşa: "Ger Endülüs olmasa Ziyadar, Kim Avrupa'yı ederdi bîdar" demiştir. Günümüzdeki Türkçe ile bu 
sözün anlamı, "Eğer Endülüs 1şık saçmasaydı, Avrupa'yı kim uyandırırdı" anlamındadır (Kayadibi, 2001).

Nizamiye Medreselerinin kuruluşunda etkili olan düşünceler ve medreselerin yapılanma biçimi ile özellikle vakıf okulu düşüncesi gerçekten Batı'daki birçok üniversite için ilham kaynağ 1 olmuştur. Yine Makdisi (2004)'nin belirttiğine göre 13. yüzyılda Oxford'un bir vakıf üniversitesi olarak yapılandırılmasında Nizamiye Medreseleri en önemli örneği oluşturmuştur (Okumuşlar, 2008).

Günümüzde medreselerin en gelişmiş örnekleri Anadolu'da bulunmaktadır. Dolayısıyla Türkiye'de bulunan ve hala ayakta duran Selçuklu medreseleri ve Beylikler Döneminde kurulan medreseler Tablo 2'de sınıflandırılmıştır.

Tablo 2. Türkiye'deki Medreselere ait bilgiler

\begin{tabular}{|c|c|c|c|c|}
\hline Medrese Adı & Medrese Yeri & Yapılış Tarihi & Yaptıran Kişi & Eğitim Türü \\
\hline Taş Medrese & Afyon/ Çay & 1278 & Yusuf bin Yakup Bey & ------------ \\
\hline $\begin{array}{l}\text { Amasya Gök } \\
\text { Medrese }\end{array}$ & Amasya & 1267 & Seyfeddin Torumtay & Tip \\
\hline $\begin{array}{l}\text { Atabey Armağan } \\
\text { Medresesi }\end{array}$ & Antalya & 1239 & $\begin{array}{l}\text { Armağan-şah bin } \\
\text { Abdullah }\end{array}$ & ------------ \\
\hline Karatay Medresesi & Antalya & $1250-1251$ & Celaleddin Karatay & |----------- \\
\hline İhlasiye Medresesi & Bitlis & 1216 & $\begin{array}{l}\text { _ } 1589^{\prime} \text { da } 5 . \text { Şerefhan } \\
\text { onardi }\end{array}$ & ------------ \\
\hline $\begin{array}{l}\text { Erzurum Çifte } \\
\text { Minareli Medrese }\end{array}$ & Erzurum & 1253 & $\begin{array}{l}\text { Hüdavend (Hundi) } \\
\text { Hatun }\end{array}$ & |---------- \\
\hline $\begin{array}{l}\text { Ümmühan Hatun } \\
\text { Medresesi }\end{array}$ & $\begin{array}{l}\text { Eskişehir/ } \\
\text { Seyitgazi }\end{array}$ & $1205-11$ & $\begin{array}{l}\text { 1.Gryaseddin } \\
\text { Keyhüsrev }\end{array}$ & İslami İlimler \\
\hline $\begin{array}{l}\text { Dündar Bey } \\
\text { medresesi }\end{array}$ & Isparta & 1301 & $\begin{array}{l}\text { Hamidoğlu Dündar } \\
\text { Bey }\end{array}$ & ------------ \\
\hline $\begin{array}{l}\text { Atabey Ertokuş } \\
\text { Medresesi }\end{array}$ & Isparta & 1224 & Ertokuş bin Abdullah & $\begin{array}{l}\text { Astronomi ve Tıp } \\
\text { (su sesi ile eğitim) }\end{array}$ \\
\hline $\begin{array}{l}\text { Gevher Nesibe } \\
\text { Hatun Darüşşifası }\end{array}$ & Kayseri & 1206 & $\begin{array}{l}\text { 1.Giyaseddin } \\
\text { Keyhüsrev }\end{array}$ & Tıp, Hastane \\
\hline $\begin{array}{l}\text { Kayseri Hunat } \\
\text { Hatun Medresesi }\end{array}$ & Kayseri & 1237 & Mahperi Hunat Hatun & ---------- \\
\hline $\begin{array}{l}\text { Kayseri Hoca } \\
\text { (Koca) Hasan } \\
\text { Medresesi }\end{array}$ & Kayseri & 1193 & Koca Hasan & ----------- \\
\hline $\begin{array}{l}\text { Seraceddin } \\
\text { Medresesi }\end{array}$ & $\begin{array}{l}\text { Kayseri/ } \\
\text { Melikgazi }\end{array}$ & $1238-1239$ & Siraceddin Lala Bedir & ----------- \\
\hline $\begin{array}{l}\text { Sahabiye } \\
\text { (Sahibiyye) } \\
\text { Mederesesi }\end{array}$ & Kayseri & 1267 & Sahip Ata & ----------- \\
\hline $\begin{array}{l}\text { Kırşehir Cacabey } \\
\text { Medresesi }\end{array}$ & Kırşehir & 1272 & $\begin{array}{l}\text { Cebrail bin Caca } \\
\text { (Cacabey) }\end{array}$ & $\begin{array}{c}\text { Astronomi } \\
\text { Yüksekokulu }\end{array}$ \\
\hline Ali Gav Medresesi & Konya & 13. veya 12. Yy.(?) & Ali Gav & ------------ \\
\hline Sırçalı Medrese & Konya & 1242 & Bedreddin Muslih & F1kıh \\
\hline Karatay Medresesi & Konya & 1251 & Celaleddin Karatay & $F_{1 k 1 h}$ \\
\hline $\begin{array}{l}\text { İnce Minareli } \\
\text { Medrese }\end{array}$ & Konya & 1264 & $\begin{array}{l}\text { Sahip Ata Fahreddin } \\
\text { Ali }\end{array}$ & Hadis \\
\hline
\end{tabular}




\begin{tabular}{|c|c|c|c|c|}
\hline $\begin{array}{l}\text { Şemseddin Ebu } \\
\text { Said Altun Aba } \\
\text { İpekçi Medrese }\end{array}$ & Konya & 1200 & II. Kılıç Arslan & F1k1h \\
\hline $\begin{array}{l}\text { Akşehir Taş } \\
\text { Medrese }\end{array}$ & $\begin{array}{l}\text { Konya/ } \\
\text { Akşehir }\end{array}$ & 1250 & Fahreddin Ali & Fikıh, Tip \\
\hline $\begin{array}{l}\text { Hatuniye } \\
\text { Medresesi }\end{array}$ & Mardin & 1185 & Sitti Razviye & ------------ \\
\hline $\begin{array}{l}\text { Mardin } \\
\text { Eminüddin } \\
\text { Külliyesi }\end{array}$ & Mardin & $1108-1112$ & $\begin{array}{l}\text { Necmeddin İlgazi ve } \\
\text { kardeşi Eminüddin }\end{array}$ & ------------ \\
\hline Niğde Ak Medrese & Niğde & 1409 & Ali Bey & ----------- \\
\hline Şifaiye Medresesi & Niğde & 1217 & 1. İzzeddin Keykavus & Tip \\
\hline Pervane Medresesi & Sinop & 1261 & Süleyman Pervane & ------------ \\
\hline $\begin{array}{l}\text { Keykavus } \\
\text { Darüşşifası }\end{array}$ & Sivas & 1217 & 1. İzzeddin Keykavus & Tip, Hastane \\
\hline $\begin{array}{l}\text { Sivas Gök } \\
\text { Medrese }\end{array}$ & Sivas & 1271 & $\begin{array}{l}\text { Sahıp Ata Fahreddin } \\
\text { Ali }\end{array}$ & Fikıh \\
\hline Divriği Medresesi & Sivas & 1243 & Melike Turan Melek & Fikıh ve Tip \\
\hline $\begin{array}{l}\text { Sivas Şifahiye } \\
\text { Medresesi }\end{array}$ & Sivas & 1217 & 1. İzzeddin Keykavus & Tip \\
\hline $\begin{array}{l}\text { Sivas Buruciye } \\
\text { Medresesi }\end{array}$ & Sivas & 1271 & $\begin{array}{l}\text { 3. Glyaseddin } \\
\text { Keykavus }\end{array}$ & $\begin{array}{c}\text { Fizik Kimya } \\
\text { Astronomi }\end{array}$ \\
\hline $\begin{array}{l}\text { Yağıbasan } \\
\text { Medresesi }\end{array}$ & Tokat & 1157 & Nizamettin Yağıbasan & ------------ \\
\hline
\end{tabular}

Yukarıdaki tabloda görüldüğü gibi Selçuklulardan sonra Anadolu'da Beylikler döneminde de medreseler yapılmıştır. Bu noktaya kadar gelişerek gelen medrese anlayışı Osmanlılara kaynaklık teşkil etmiştir (Hızlı, 1987).

Medrese külliyeleri incelendiğinde darüşşfası/hastanesi olan büyük medreselerin dönemin sultanı tarafından yaptırıldığg anlaşılmaktadır. Ancak birçok büyük boyutlu medreselerin genellikle vezirler ve diğer önemli devlet adamları tarafından yaptırılmış olduğu da görülmektedir (Doğan, 2013).

Anadolu Selçukluları tarafından, çocuklara okuma-yazma öğretmek amacıyla her mescit yanında kurulan ilkokullardan başka, birçok ilde medreseler kurulmuştur. Özellikle Moğol istilası Doğu'dan birçok bilim adamı, şair, mutasavvıf ve din aliminin Anadolu'ya gelip yerleşmesini, bu bölgedeki ilim faaliyetlerini arttırmış ve buna bağlı olarak medreselerin ilmi açıdan ün kazanmasına neden olmuştur (Köprülü, 1972).

Büyük Selçuklulardan sonra Türklerde medrese kurma çalışmaları Osmanlılar döneminde de devam etmiştir. Nizamiye medreseleri daha sonraki dönemlerde kurulan birçok medreseye örnek olmuştur. Osmanlı döneminde de imparatorluğun Kirman, Suriye, Irak ve Anadolu gibi çeşitli bölgelerinde çok sayıda medreseler kurulmuştur (Öngül, 2003).

\section{Sonuç ve Tartışma}

Devletin, eğitim ve öğretimi en önemli görevleri arasında kabul ederek bireylerinin tamamına eşit olanaklar içinde, bilime dayall, düşündüren, bilinçlendiren 
nitelikte bir eğitim ve öğretim görmesini sağlamayı amaç edinmesi gerekmektedir. Bu bağlamda devletin, eğitim faaliyetlerini planlanması ve fırsat eşitliğini sağlamak için gerekli önlemleri alması en önemli görevlerinin en başında yer almaktadır (Sarıer, 2010; İnan ve Demir, 2018)

Devletin eğitim ve öğretimde fırsat eşitliğini sağlamaya yönelik girişimleri sonucunda mali, iktisadi veya sosyal içerikli bir dizi transfer gerçekleştiği söylenebilmektedir (Lazenby 2016; Westen, 1985). Eğitim ve öğretimde toplumsal talep ve beklentilerin karşılanabilmesi için sadece salt eğitim sisteminin işleyişine yönelik politikaların değil, gelir dağılımının düzeltilmesi, istihdam olanaklarının arttırılması, bölgesel farklıkların giderilmesi gibi iktisadi ve sosyal yapıyı iyileştirecek makro politikaların da eş anlı bir biçimde uygulanması gerekmektedir. Ancak, bu koşulların varlığında eğitimde ve devletin sunduğu öteki olanaklarda da fırsat eşitliğinin sağlanması amacına ulaşılabilmektedir.

Eğitimde ve özellikle yükseköğretim kurumlarında fırsat eşitliğinin sağlanması ilkesinin tarihsel süreç içerisindeki gelişimine ve devlet eliyle fırsat eşitliği yaratılması konusuna baktığımızda bu ilke ve konunun ilk olarak ortaya çıkışının Türk-İslam Devleti olan Selçuklulara dayandığını görülmektedir. Eğitim tarihi alanındaki literatürde Türk toplumlarının eğitim tarihi konusunda büyük bir boşluk olduğunu anladık. Özellikle literatür taraması yaptığımızda geçmişte hüküm sürmüş Türk Devletlerinin eğitim hayatının incelenmesi gerektiği kanısına vardık.

Bu yüzden bu konuya ilginin artması ve ayrıntılı çalışmaların yapılarak Türklerin eski dönem eğitim kurumlarının araştırması, incelemesi ve anlatılması gerekmektedir. Bu sayede, geçmişte yaşamış Türk toplumlarının felsefesini keşfedersek, bu toplumun geleceğe yönelik planları geliştirmede de o denli başarılı olabiliriz. Şairin dediği gibi, geçmişi büyük olan milletlerin geleceği de büyük olacaktır.

Bilindiği gibi, Selçuklular tarihte 1,5 yüzylllık bir ömre sahip olduktan sonra parçalara ayrılarak yıkılmıştır. Ancak, çok kısa bir süre sonra kurulan Osmanlı Devleti, 6,5 yüzyıla yakın ömür süren (Köymen, 1993; Sönmez ve Celkan, 2018) bir Cihan İmparatorluğu kurarak Selçukluların tecrübesinden faydalanmışlardır. Türkiye Cumhuriyeti de kendinden önceki iki Türk İmparatorluğunun tecrübelerini yeterince kullanacak olursa, eğitimde ve özellikle yükseköğretim kurumlarında fırsat eşitliğinin sağlanması konusunda tüm Dünyada en iyi örneği oluşturacak ve sonsuza dek yaşayabilecektir.

\section{Kaynaklar}

Aslankurt, B. (2013). Eğitimde Kuşaklararası Hareketlilik- Fırsat Eşitliğinde Türkiye Nerede? Türkiye Ekonomi Politikaları Araştırma Vakfı (tepav). 
Aydın, A. (2000). Zorunlu Temel Eğitim Uygulaması ve Çözüm Bekleyen Sorunlar, Pamukkale Üniversitesi Eğitim Fakültesi Dergisi, 8(8), 98-103.

Balcı, A. (2001). Sosyal Bilimlerde Araştırma: Yöntem teknik ve ilkeler, Pegem A, Ankara

Başaran, İ.E. (1982). Temel Eğitim ve Yönetimi, Ankara Üniversitesi Eğitim Fakültesi yayını No: 112, Ankara.

Biçer, B. (2013). Kuruluş Devrinde Nizamiye Medreselerinin Müderrisleri, Tarih Okulu Dergisi, Aralık, Yıl:6, Sayı: XVI, 263-287.

Brockelmann, C. (1991). Tarihu'l-Edebi'l-Arab V, (trc. A. En-Neccâr), Kahire

Çelebi, A. (1983). İslam'da Ĕ̆gitim Öğretim Tarihi, çev.: A. Yardım, İstanbul.

Dağ, M. \& Öymen, H. R. (1976). İslam Ĕğitim Tarihi, Ankara, 118.

Doğan, N. Ş. (2013). Orta Çă̆'da Anadolu'nun Eğitim Mekânları: Selçuklu MedreseleriDarüşşifalarından Örnekler, Hacettepe Üniversitesi Eğitim Fakültesi Dergisi, 28(2), 429-443.

Ergün, M. (1997). Ĕ̆itim Sosyolojisi, Ocak Yayınları, 4. Baskı, Ankara.

Göksu, E. (2018). Bilge Vezir Nizam'ül Mülk, 1. Baskı, Erdem Yayınları, İstanbul.

Hızlı, M. (1987). Kuruluşundan Osmanlılara Kadar Medreseler, Uludağ Üniversitesi, İlahiyat Fakültesi, 2(2), 273-281.

Illich, I. (2013). Okulsuz Toplum, Türkçesi: Mehmet ÖZAY, Şule Yayınları, İstanbul.

İnan, M. \& Demir, M. (2018). Eğitimde Fırsat Eşitliği ve Kamu Politikaları: Türkiye Üzerine Bir Değerlendirme, Ankara Hacı Bayram Veli Üniversitesi İktisadi ve İdari Bilimler Fakültesi Dergisi, 20(2), 337-359.

Karagözoğlu, C. (1985). Atatürk'ün Eğitim Savaşı, Atatürk Araştırma Merkezi Dergisi, 2(4), Ankara, 210.

Karasar, N. (1994). Bilimsel Araştırma Yöntemi, 3A araştırma eğitim, danışmanlık

Kayadibi, F. (2001). İslam Dininin Eğitime Verdiği Önem, İstanbul Üniversitesi İlahiyat Fakültesi Dergisi, 4, 33-44

Köprülü, M. F. (1972). Osmanlı İmparatorluğu'nun Kuruluşu, Ankara.

Köprülü, M. F. (1980). Türk Edebiyatı Tarihi, 2. Basım., İstanbul.

Köymen, M. A. (1975). Alp Arslan Zamanı Selçuklu Kültür Müesseseleri, Selçuklu Araştırmaları Dergisi, IV.

Köymen, M. A. (1993). Büyük Selçuklu Imparatorluğu Tarihi, Türk Tarih Kurumu Yayınları, Ankara.

Köymen, M. A. (2001). Büyük Selçuklu Imparatorluğu Tarihi Alp Arslan ve Zamanı, cilt: 3, Ankara: Türk Tarih Kurumu.

Küçüker, E. (2010). Türkiye'de Eğitim Planlaması Neyi Hedefliyor? ICONTE, International Conference on New Trends in Education and Their Implications, 11-13 November, Antalya, Turkey. ISBN: 978-605-364-104-9, 153-157. 
Lazenby, H. (2016). What is equality of opportunity in education?, Theory and Research in Education, 14(1), 65-76.

Leiser, G. (1986). Notes on Madrasa in Medival Islamic Society, Muslim World, 76, 16-23.

Makdisi, G. (2004). Orta Çă̆g'da Yükseköğretim, İslam Dünyası ve Hristiyan Batı, çev. A. H. Çavuşoğlu, H. T. Başoğlu, Gelenek Yayınları, İstanbul.

Ocak, A. (2009). Selçuklu Medreselerinin Mağrip ve Endülüs Üzerindeki Etkileri, Turkish Studies, 4(3),1622-1647.

Okumuşlar, M. (2008). Ehl-i Sünnetin Kurumsallaşmasında Nizamiye Medreselerinin Etkisi, Marife, Bahar, 1, 137-148

Onuncu Kalkınma Planı (2014-2018), (2013). T.C. Kalkınma Bakanlığı, Ankara 2013, Eğitim Sisteminin Kalitesinin Artırılması Özel İhtisas Komisyonu Raporu.

Öngül, A. (2003). Selçuklularda Eğitim Faaliyetleri ve Yetişen İlim Adamlarına Genel Bir Bakış, Celal Bayar Üniversitesi Sosyal Bilimler Enstitüsü Dergisi, 1(2), 67-78.

Pakalın, M. Z. (1971). Osmanlı Tarih Deyimleri ve Terimleri Sözlüğ̈̈, cilt II, 436.

Rice, T. T. (2015). Anadolu Selçuklu Tarihi, çev.: T. K. Taştan, Nobel Akademik Yayıncılık.

Sayılı, A. (1947- 1948). Higher Education in Medieval Islam, Ankara Üni. Yıllığı.

Sarıer, Y. (2010). "Ortaöğretime Giriş Sınavları (OKS-SBS) ve PISA Sonuçları Işı̆̆ında Eğitimde Fırsat Eşitliğinin Değerlendirilmesi", Ahi Evran Üniversitesi Eğitim Fakültesi Dergisi, 11(3), 107-129.

Serçe, H. (2016). "Eğitimin Politik Temelleri”, https://huseyinserce.wordpress.com/, (Erişim Tarihi: 03.03.2016), 1-35.

Sönmez, S. \& Celkan, H. Y. (2018). Anadolu'daki Selçuklular ve Beylikler Dönemi Medreseler, Atatürk Üniversitesi Sosyal Bilimler Enstitüsü Dergisi, 22(3), 1457-1465.

Suğur, N. (2008). "Eğitim ve Toplumsal Hareketlilik", Boyacı, A. (Editör): Eğitim Sosyolojisi ve Felsefesi, Eskişehir: Anadolu Üniversitesi Açıköğretim Fakültesi Yayını No: 973.

Tan, M. (1987). "Eğitsel Fırsat Eşitliği (Sosyolojik Bir Kavram Olarak Gelişimi)", Ankara Üniversitesi Ĕ̆itim Bilimleri Fakültesi Dergisi, 20(1), 245-259.

Tekindağ, M. Ş. (1973). Medrese Dönemi, Cumhuriyetin 50. Yılında, İstanbul Üniversitesi, 3-54.

Tibawi A. L. (1962). Origin and Character of al-madrasah, Bulletin of the School of Oriental and African Studies, University of London, (25) 1/3, 225-238.

Yurdaydın, H. G. (1971). İslam Tarihi Dersleri, Ankara.

Westen, P. (1985), The concept of equality of opportunity, Ethics, 95, 837-850.

Winkelmann, M. J. (2005). 'From Behind the Curtain' a Study of a Girls' Madrasa in India, Amsterdam: Amsterdam University Press.

Zeydan, C. (1329). Medeniyet-i İslamiye Tarihi, çev.: Z. Megamiz, cilt III, İstanbul. 
